\title{
Material properties of perovskites in the quasi-ternary system $\mathrm{LaFeO}_{3^{-}}$ $\mathrm{LaCoO}_{3}-\mathrm{LaNiO}_{3}$
}

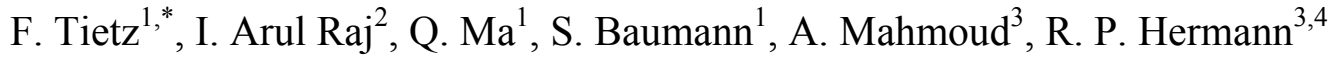 \\ ${ }^{1}$ Forschungszentrum Jülich GmbH, Institute of Energy and Climate Research, Materials \\ Synthesis and Processing (IEK-1), D-52425 Jülich, Germany \\ ${ }^{2}$ Central Electrochemical Research Institute, Karaikudi 630 006, Tamil Nadu, India \\ ${ }^{3}$ Forschungszentrum Jülich GmbH, Jülich Centre for Neutron Science JCNS and Peter Grünberg \\ Institute PGI, JARA-FIT, D-52425 Jülich, Germany \\ ${ }^{4}$ Materials Science and Technology Division, Oak Ridge National Laboratory, Oak Ridge, \\ Tennessee 37831, USA
}

Notice: This manuscript has been authored by UT-Battelle, LLC under Contract No. DE-AC05-00OR22725 with the U.S. Department of Energy. The United States Government retains and the publisher, by accepting the article for publication, acknowledges that the United States Government retains a non-exclusive, paid-up, irrevocable, worldwide license to publish or reproduce the published form of this manuscript, or allow others to do so, for United States Government purposes. The Department of Energy will provide public access to these results of federally sponsored research in accordance with the DOE Public Access Plan (http://energy.gov/downloads/doe-publicaccess-plan).

\footnotetext{
* Corresponding author, tel. +49 2461 61-5007, fax +49 2461 61-2455, email f.tietz@,fz-juelich.de
} 


\begin{abstract}
An overview is presented on the variation of electrical conductivity, oxygen permeation, and thermal expansion coefficient as a function of the composition of perovskites in the quasiternary system $\mathrm{LaFeO}_{3}-\mathrm{LaCoO}_{3}-\mathrm{LaNiO}_{3}$. Powders of thirteen nominal perovskite compositions were synthesized under identical conditions by the Pechini method. The powder X-ray diffraction data of two series, namely $\mathrm{La}\left(\mathrm{Ni}_{0.5} \mathrm{Fe}_{0.5}\right)_{1-x} \mathrm{Co}_{x} \mathrm{O}_{3}$ and $\mathrm{LaNi}_{0.5-x} \mathrm{Fe}_{x} \mathrm{Co}_{0.5} \mathrm{O}_{3}$, are presented after the powders had been sintered at $1100^{\circ} \mathrm{C}$ for $6 \mathrm{~h}$ in air. The measurements revealed a rhombohedral structure for all compositions except $\mathrm{LaNi}_{0.5} \mathrm{Fe}_{0.5} \mathrm{O}_{3}$ for which $60 \%$ rhombohedral and 40\% orthorhombic phase was found. The maximum DC electrical conductivity value of the perovskites at $800{ }^{\circ} \mathrm{C}$ was $1229 \mathrm{~S} \mathrm{~cm}^{-1}$ for the composition $\mathrm{LaCoO}_{3}$ and the minimum was $91 \mathrm{~S} \mathrm{~cm}^{-1}$ for the composition $\mathrm{LaCo}_{0.5} \mathrm{Fe}_{0.5} \mathrm{O}_{3}$. The oxygen permeation of samples with promising conductivities at $800^{\circ} \mathrm{C}$ was one order of magnitude lower than that of $\mathrm{La}_{0.6} \mathrm{Sr}_{0.4} \mathrm{Co}_{0.8} \mathrm{Fe}_{0.2} \mathrm{O}_{3}$ (LSCF). The highest value of $0.017 \mathrm{ml} \mathrm{cm}^{-2} \mathrm{~min}^{-1}$ at $950{ }^{\circ} \mathrm{C}$ was obtained with $\mathrm{LaNi}_{0.5} \mathrm{Co}_{0.5} \mathrm{O}_{3}$. The coefficients of thermal expansion varied in the range of $13.2 \times 10^{-6} \mathrm{~K}^{-1}$ and $21.9 \times 10^{-6} \mathrm{~K}^{-1}$ for $\mathrm{LaNi}_{0.5} \mathrm{Fe}_{0.5} \mathrm{O}_{3}$ and $\mathrm{LaCoO}_{3}$, respectively. ${ }^{57} \mathrm{Fe}$ Mössbauer spectroscopy was used as probe for the oxidation states, local environment and magnetic properties of iron ions as a function of chemical composition. The substitution had a great influence on the chemical properties of the materials.
\end{abstract}

Keywords: perovskites, electrical conductivity, thermal expansion, oxygen permeation, Mössbauer spectroscopy 


\section{Introduction}

Solid oxide fuel cells (SOFCs) are operated at temperatures between 700 and $900{ }^{\circ} \mathrm{C}$ leading to physical and chemical degradation of SOFC components. Thus, attempts are continuously being made to increase the thermal compatibility of these components and to decrease the operating temperature and start-up time $[1,2]$. The various degradation phenomena include cracking, delamination, grain growth, chemical decomposition, interdiffusion, etc. [3].

The cathode materials most often applied in SOFCs are perovskites of the series $\mathrm{La}_{1-\mathrm{x}} \mathrm{Sr}_{\mathrm{x}} \mathrm{MnO}_{3}$ (LSM), $\mathrm{La}_{1-\mathrm{x}} \mathrm{Sr}_{\mathrm{x}} \mathrm{Fe}_{1-\mathrm{y}} \mathrm{Co}_{\mathrm{y}} \mathrm{O}_{3}$ (LSCF) or $\mathrm{La}_{1-\mathrm{xSr}} \mathrm{CoO}_{3}$ (LSC) with $0.2<\mathrm{x}<0.4$ [4,5,6]. In former systematic studies of the properties of such perovskites it was observed that the Co content has the strongest impact on electrical conductivity and thermal expansion $[7,8,9]$, whereas the oxygen nonstoichiometry does not vary very much and is low for compositions with $\mathrm{x}=0.2$ [8] Therefore it has been assumed that the Sr-free compositions investigated here also do not have a significant oxygen nonstoichiometry as will be discussed later.

One problem that arises during SOFC operation is the reaction of the cathode with ferritic steel which is usually used as metallic interconnecting parts due to the release of chromium. The most volatile compound is a chromium acid, $\mathrm{CrO}_{2}(\mathrm{OH})_{2}[10]$, which is transported with the oxidant gas through the cathode to the cathode/electrolyte interface. In the case of LSM cathodes, the $\mathrm{Cr}^{+6}$-containing molecules compete with the oxygen molecules for the electrochemically active sites and block them after reduction to $\mathrm{Cr}^{+3}$ [10]. After the initial electrocatalytic blocking, the ongoing transport and reduction of chromium species lead to decomposition of the perovskite material and the formation of $(\mathrm{Mn}, \mathrm{Cr})_{3} \mathrm{O}_{4}$ spinels [11,12]. In contrast, LSCF (and LSC) cathodes are much more stable against Cr-poisoning than LSM and no enrichment of chromium was found 
at the LSCF/electrolyte interface in long-term tests [13], presumably due to different overvoltages of the cathodes for oxygen and $\mathrm{CrO}_{2}(\mathrm{OH})_{2}$ reduction. Instead, the LSCF cathode degrades by a steady release of strontium from the perovskite lattice leading to a continuous depletion of strontium by $50 \%$ at the outer surface after the two years of operation [13]. The released strontium, very likely as volatile $\mathrm{Sr}(\mathrm{OH})_{2}$, reacts with the gaseous $\mathrm{CrO}_{2}(\mathrm{OH})_{2}$ and forms $\mathrm{SrCrO}_{4}$ crystals at the outer surface of the cathode [13], very similar to the results in model experiments where an LSCF cathode was attached to steel interconnects $[14,15]$. The depletion of Sr in LSCF leads to deterioration of electrical conductivity and electrocatalytic activity of the cathode. A more detailed review of interconnect properties and the interaction with cathodes has been published very recently [16].

Similar or the same perovskites have also been investigated as oxygen transport membranes, which extract oxygen from air and/or provide oxygen to a chemical reaction [17]. The presence of alkaline-earth elements, such as Sr, can lead to degradation phenomena when the gas stream contains acidic gases, such as $\mathrm{CO}_{2}$ or $\mathrm{SO}_{2}$, by forming carbonates or sulfates $[18,19]$.

In this work, the development of Sr-free perovskite materials has been initiated in order to avoid the continuous depletion of $\mathrm{Sr}$ and the related performance degradation of SOFCs and membranes. We have selected the quasi-ternary system of $\mathrm{LaCoO}_{3}-\mathrm{LaNiO}_{3}-\mathrm{LaFeO}_{3}$ for detailed investigations of these perovskites because $\mathrm{LaNi}_{0.6} \mathrm{Fe}_{0.4} \mathrm{O}_{3}$ (LNF) has been reported to have SOFC-compatible physical properties [20], good electrochemical performance [21,22] and chemical stability [23] against chromium oxyhydroxides released from the metallic interconnects used in SOFC stacks. 


\section{Experimental}

Thirteen different perovskite compositions were prepared by the Pechini method [24] using the nitrate solutions of $\mathrm{La}, \mathrm{Co}, \mathrm{Ni}$ and $\mathrm{Fe}$ in the corresponding cation ratios. Mother solutions were prepared from each salt and the weight of the metal ions present in a given volume of the solution was determined by quantitative gravimetric analysis after heat treatment at $800{ }^{\circ} \mathrm{C}$ in air. The exact weights of the solutions were taken and mixed with citric acid solution, which had already been prepared in the molar ratio of 2 moles citric acid to 1 mole metal cations and stirred well in a tall quartz beaker. These colored solutions were continuously stirred while being heated at $80{ }^{\circ} \mathrm{C}$. After $3 \mathrm{~h}$, exactly $1 \mathrm{ml}$ ethylene glycol to $1 \mathrm{~g}$ citric acid was added to the warm solutions in steps of $20 \mathrm{ml}$. The volume of ethylene glycol added to the solutions was slightly more than the stoichiometric composition necessary to achieve complete polyesterification with the citric acid. The obtained mixtures were heated at $220^{\circ} \mathrm{C}$ and stirred continuously until most of the solvent had evaporated. The viscosity of the hot solutions decreased with time and stirring became very difficult. The color of the solutions turned to deep brown and then to black. During this preparation, ignition was observed with the evolution of a deep brown stream of nitrogen oxides. The black masses obtained after complete evaporation were like resins and were subjected to calcination in air at $700{ }^{\circ} \mathrm{C}$ for $3 \mathrm{~h}$ in a quartz container. This was carried out in a small furnace equipped with a gas-removing device in order to avoid the harmful effects of nitrogen oxides and of the burn-out of organic residues. The powders obtained after calcination were black in color and were ground well prior to further measurements.

The powders were subjected to chemical analysis using ICP-OES to ensure stoichiometry. The experimental error for each cation is $3 \mathrm{wt} \%$. Converting the experimental data into molar 
fractions (see Table 1), the error is then $3 \mathrm{at} \%$. The crystalline phase compositions of samples heat-treated at $1100{ }^{\circ} \mathrm{C}$ for $6 \mathrm{~h}$ were determined by X-ray powder diffraction (XRD) using a Siemens D5000 diffractometer with CuKa radiation. Lattice parameter determination and quantitative phase analysis were performed by the Rietveld method using the Total Pattern Analysis Solution (TOPAS) profile fitting software (Bruker AXS GmbH, Karlsruhe Germany). Crystal structures were obtained from the Inorganic Crystal Structure Database (ICSD, FIZ Karlsruhe, Germany) and only modified to match the nominal chemical composition of the samples. Used ICSD collection codes are $164900\left(\mathrm{LaCoO}_{3}\right.$, space group $\left.R \overline{3} c\right)$ and 84938 $\left(\mathrm{LaNi}_{0.6} \mathrm{Fe}_{0.4} \mathrm{O} 3\right.$, space group Pnma).

The powders calcined at $700{ }^{\circ} \mathrm{C}$ were ball-milled for $24 \mathrm{~h}$ with zirconia balls in ethanol. Afterwards, they were uniaxially pressed to form rectangular bars with dimensions of $40 \times 5 \times 4$ $\mathrm{mm}^{3}$ and sintered at $1380^{\circ} \mathrm{C}$ for $6 \mathrm{~h}$ in air for thermal expansion and conductivity measurements. The relative densities of the sintered samples were all above $95 \%$ theoretical density. In the same way, pellets ( $\varnothing 22 \mathrm{~mm}, 1.3 \mathrm{~mm}$ in thickness) were prepared to measure the oxygen permeation rate. The relative densities of the sintered samples were also all above $95 \%$. The samples were cut to a diameter of $14.7 \mathrm{~mm}$ and $1 \mathrm{~mm}$ thickness and mounted in a quartz glass holder manufactured in-house as described elsewhere [25]. $250 \mathrm{ml}_{\mathrm{N}} \min ^{-1}$ air and $50 \mathrm{ml}_{\mathrm{N}} \mathrm{min}^{-1}$ argon were supplied as feed and sweep gases, respectively. The permeate, i.e. oxygen-enriched argon, was analyzed using a mass spectrometer (Omnistar, Pfeiffer Vacuum, Germany). The sample holder was first heated to $1000^{\circ} \mathrm{C}$ in order to seal the specimens in the glass compartments using gold rings. After thermal equilibration, the oxygen permeation rate was measured in approx. 50 K steps down to a temperature of $700{ }^{\circ} \mathrm{C}$. 
The electrical conductivity $(\sigma)$ of the sintered samples was measured by a four-probe DC device between $25{ }^{\circ} \mathrm{C}$ and $900{ }^{\circ} \mathrm{C}$ in air using silver wires and silver paste as contacts. The activation energies for electronic conduction were determined from Arrhenius plots using the measured $\sigma$ values according to

$\sigma T=A \cdot e^{-\frac{E a}{R T}}$

The discussion related to compositional dependence of the conductivity was restricted to $800{ }^{\circ} \mathrm{C}$ for comparison with the literature.

The thermal expansion was measured between room temperature and $900{ }^{\circ} \mathrm{C}$ using a Netzsch DIL 402C dilatometer.

Iron-57 Mössbauer spectra were obtained using a constant-acceleration spectrometer. The Mössbauer spectral measurements were carried out using a closed-cycle cryostat (Janis SH-850) and with a ${ }^{57} \mathrm{Co}(\mathrm{Rh})$ source at room temperature. The Mössbauer spectral absorbers were prepared with $\sim 26 \mathrm{mg} \mathrm{cm}^{-2} \mathrm{LaCo}_{x} \mathrm{Fe}_{y} \mathrm{Ni}_{z} \mathrm{O}_{3}$ materials mixed with boron nitride. The spectrometer was calibrated at room temperature with $\alpha$-iron foil. The measurements were carried out at two velocity ranges: a small velocity range $( \pm 3 \mathrm{~mm} / \mathrm{s})$ with optimal energy resolution at room temperature and a large velocity range $( \pm 12.1 \mathrm{~mm} / \mathrm{s})$ at which all other spectra were measured at $10 \mathrm{~K}$ showing the entire magnetic hyperfine splitting. The room-temperature Mössbauer spectra were fitted with one or two Lorentzian doublets and with one or two sextets for the magnetically split spectra recorded at $10 \mathrm{~K}$. The relative population of the Fe-bearing compounds was estimated from their corresponding fitted area in each sample. The validity of fits was judged on the basis of minimizing the number of parameters and $\chi^{2}$ values. 


\section{Results and Discussion}

\section{Chemical analysis and XRD}

The ternary diagram showing the selected compositions for the present investigations with the corresponding labels is shown in Fig. 1. The targeted compositions and the resulting elemental analysis data obtained for the powders by ICP analysis are presented in Table 1. The chemical analysis data of the synthesized powders show no significant variations from the targeted compositions. In most cases, the differences between nominal and observed stoichiometry are below the accuracy limitation (3 at $\%$ ) of the analytical technique.

The comparative XRD patterns obtained for the two series of oxides, $\mathrm{La}\left(\mathrm{Ni}_{0.5} \mathrm{Fe}_{0.5}\right)_{1-x} \mathrm{Co}_{x} \mathrm{O}_{3}$ and $\mathrm{LaNi}_{0.5-x} \mathrm{Fe}_{x} \mathrm{Co}_{0.5} \mathrm{O}_{3}$, are presented in Fig. 2. It is evident that there are only very small impurities

of $\mathrm{La}_{2} \mathrm{O}_{3}$ visible in the XRD patterns of $\mathrm{La}\left(\mathrm{Ni}_{0.5} \mathrm{Fe}_{0.5}\right)_{0.4} \mathrm{Co}_{0.6} \mathrm{O}_{3}, \mathrm{La}\left(\mathrm{Ni}_{0.5} \mathrm{Fe}_{0.5}\right)_{0.2} \mathrm{Co}_{0.8} \mathrm{O}_{3}$, and $\mathrm{LaCoO}_{3}\left(\right.$ at $\left.2 \Theta=30^{\circ}\right)$ and that the samples are well crystallized in the hexagonal phase with the exception of $\mathrm{LaNi}_{0.5} \mathrm{Fe}_{0.5} \mathrm{O}_{3}$, where the reflections are broadened and the peak profiles can be better refined as a phase mixture of $40 \%$ orthorhombic and $60 \%$ hexagonal phase. The broadening of the reflections of $\mathrm{LaNi}_{0.5} \mathrm{Fe}_{0.5} \mathrm{O}_{3}$ is regarded as an overlap of the reflections of both phases. As an example, the highest peak at $33^{\circ}$ (see inset of Figure 2a) is composed of a doublet arising from the hexagonal phase and a single reflection of the orthorhombic phase, mainly overlapping with the left peak of the doublet. This overlap is also visible for other reflections, e.g. at $53^{\circ}$. The lattice parameters, unit cell volume and density of the samples are presented in Table 2. 
In the series $\mathrm{La}\left(\mathrm{Ni}_{0.5} \mathrm{Fe}_{0.5}\right)_{1-x} \mathrm{Co}_{x} \mathrm{O}_{3}$, the rhombohedral lattice parameters $\left(\mathrm{a}_{\mathrm{r}}\right)$ of the samples decrease as the cobalt content increases, whereas for the series $\mathrm{LaNi}_{0.5-x} \mathrm{Fe}_{x} \mathrm{Co}_{0.5} \mathrm{O}_{3}$, the $\mathrm{a}_{\mathrm{r}}$ of the samples increase as iron content increases (cf. Figure 3). Similar results were also reported in Ref. [26]. The tendencies can be explained by the different ionic radii of the ions in sixfold coordination, which are 56, 54.5 and $64.5 \mathrm{pm}$ [27] for $\mathrm{Ni}^{3+}$ (low-spin) [28], $\mathrm{Co}^{3+}$ (high-spin) $[29,30]$ and $\mathrm{Fe}^{3+}$ (high-spin) [31], respectively. In the series $\mathrm{La}\left(\mathrm{Ni}_{0.5} \mathrm{Fe}_{0.5}\right)_{1-x} \mathrm{Co}_{x} \mathrm{O}_{3}, \mathrm{a}_{\mathrm{r}}$ decreases

as the cobalt content increases because the ionic radius of $\mathrm{Co}^{3+}$ is smaller than the average radius of $\mathrm{Ni}^{3+}$ and $\mathrm{Fe}^{3+}$, whereas in the series $\mathrm{LaNi}_{0.5-\mathrm{x}} \mathrm{Fe}_{x} \mathrm{Co}_{0.5} \mathrm{O}_{3}, \mathrm{a}_{\mathrm{r}}$ increases as iron content increases because the ionic radius of $\mathrm{Fe}^{3+}$ is the largest of the three ions. After conversion of the rhombohedral to the hexagonal lattice, the lattice parameters $a_{h}$ and $c_{h}$ show opposing trends so that the influence of the different transition metal cations can only be evaluated by the cell volume. A more general representation of the lattice expansion with increasing Fe and Ni content is shown in Figure 3, in which $a_{r}$ is plotted as a function of the mean ionic radius of the B-site cations $\left(\mathrm{r}_{\mathrm{B}}\right)$ using the ionic radii mentioned above.

\section{Electrical conductivity}

The Arrhenius plots of electrical conductivity of the perovskite series $\mathrm{La}\left(\mathrm{Ni}_{0.5} \mathrm{Fe}_{0.5}\right)_{1-x} \mathrm{Co}_{x} \mathrm{O}_{3}$ and $\mathrm{LaNi}_{0.5-\mathrm{x}} \mathrm{Fe}_{x} \mathrm{Co}_{0.5} \mathrm{O}_{3}$ are presented in Figs. $4 \mathrm{a}$ and $4 \mathrm{~b}$, respectively. The corresponding activation energies are listed in Table 3. 
In the series $\mathrm{La}\left(\mathrm{Ni}_{0.5} \mathrm{Fe}_{0.5}\right)_{1-x} \mathrm{Co}_{x} \mathrm{O}_{3}$, the activation energy clearly decreases with decreasing $\mathrm{Co}$ content, while in the series $\mathrm{LaNi}_{0.5-x} \mathrm{Fe}_{x} \mathrm{Co}_{0.5} \mathrm{O}_{3}$, the activation energy decreases with decreasing Fe content. Taguchi et al. [26] and Chiba et al. [20] observed similar trends for quasi-binary systems. However, the reason for these trends is still unclear. It should be noted that among these samples, $\mathrm{LaCoO}_{3}$ shows the strongest change in activation energy above and below $400{ }^{\circ} \mathrm{C}$. This is due to the high-spin $\leftrightarrow$ low-spin transition of the $d$-electrons of $\mathrm{Co}^{3+}[29]$. This difference in the mechanism of conduction at high and low temperatures is the reason why the activation energy of $\mathrm{LaCoO}_{3}$ has not been inserted in Table 3. With respect to the temperature dependence of conductivity, most of the compositions show semiconductive behavior, those with the highest conductivities $\left(\mathrm{LaNi}_{0.5} \mathrm{Fe}_{0.5} \mathrm{O}_{3}, \mathrm{LaCo}_{0.5} \mathrm{Ni}_{0.5} \mathrm{O}_{3}\right.$ and $\left.\mathrm{LaCo}_{0.5} \mathrm{Ni}_{0.4} \mathrm{Fe}_{0.1} \mathrm{O}_{3}\right)$ show nearly semimetallic behavior in the high temperature range $\left(>400^{\circ} \mathrm{C}\right)$. The variation in electrical conductivity at 800 ${ }^{\circ} \mathrm{C}$ as a function of perovskite stoichiometry is shown in Fig. 5. The compositions with the highest conductivities at $800{ }^{\circ} \mathrm{C}$ are $\mathrm{LaCoO}_{3}\left(1229 \mathrm{~S} \mathrm{~cm}^{-1}\right), \mathrm{LaNi}_{0.5} \mathrm{Co}_{0.5} \mathrm{O}_{3}\left(862 \mathrm{~S} \mathrm{~cm}^{-1}\right)$ and $\mathrm{LaCo}_{0.5} \mathrm{Ni}_{0.4} \mathrm{Fe}_{0.1} \mathrm{O}_{3}\left(795 \mathrm{~S} \mathrm{~cm}^{-1}\right)$. In [20], the electronic conductivities of $\mathrm{LaNi}_{0.6} \mathrm{Fe}_{0.4} \mathrm{O}_{3}$ and $\mathrm{LaNi}_{0.56} \mathrm{Fe}_{0.44} \mathrm{O}_{3}$ are reported as 580 and $520 \mathrm{~S} \mathrm{~cm}^{-1}$, respectively. These values are in good agreement with $532 \mathrm{~S} \mathrm{~cm}^{-1}$ found here for $\mathrm{LaNi}_{0.5} \mathrm{Fe}_{0.5} \mathrm{O}_{3}$ considering the difference in composition. In Ref. [32], a value of $290 \mathrm{~S} \mathrm{~cm}^{-1}$ is given for $\mathrm{LaNi}_{0.5} \mathrm{Fe}_{0.5} \mathrm{O}_{3}$.

In [20], a conductivity at $800{ }^{\circ} \mathrm{C}$ of $345 \mathrm{~S} \mathrm{~cm}^{-1}$ is reported for $\mathrm{LaNi}_{0.6} \mathrm{Co}_{0.4} \mathrm{O}_{3}$, which is lower than the value of $862 \mathrm{~S} \mathrm{~cm}^{-1}$ obtained here. In both cases, the literature values are based on porous samples, whereas in this study the density of the samples was close to theoretical density. The conductivity of $\mathrm{LaCoO}_{3}$ is in very good agreement with previous studies summarized in [6]. In general, the electrical conductivity decreased with decreasing Co content in the perovskites, as already reported in other systematic studies [8,33]. In this study, there is also a strong decrease in 
conductivity (at $800{ }^{\circ} \mathrm{C}$ ) for the series $\mathrm{La}\left(\mathrm{Ni}_{0.5} \mathrm{Fe}_{0.5}\right)_{1-x} \mathrm{Co}_{x} \mathrm{O}_{3}$ from $x=1$ to $x=0.6$. However, in the range of $0.6>x>1$, the conductivity starts to slightly increase again with decreasing Co content. In the series with constant Co content, the electrical conductivity decreases with increasing $\mathrm{Fe}$ content ending at $91 \mathrm{~S} \mathrm{~cm}^{-1}$ for $\mathrm{LaFe}_{0.5} \mathrm{Co}_{0.5} \mathrm{O}_{3}$. Noting the-state-of-the-art $(\mathrm{La}, \mathrm{Sr})(\mathrm{Co}, \mathrm{Fe}) \mathrm{O}_{3}$-based cathode materials have a conductivity of about $300 \mathrm{~S} \mathrm{~cm}^{-1}$ at $800{ }^{\circ} \mathrm{C}$ [34], most of the samples in this study have sufficiently high conductivity to be used as cathode materials in SOFCs.

\section{Oxygen permeation}

Fig. 6 shows the oxygen permeation rate of selected samples in the series $\mathrm{La}\left(\mathrm{Ni}_{0.5} \mathrm{Fe}_{0.5}\right)_{1-x} \mathrm{Co}_{x} \mathrm{O}_{3}$ and $\mathrm{LaNi}_{0.5-x} \mathrm{Fe}_{x} \mathrm{Co}_{0.5} \mathrm{O}_{3}$. Similar to the electrical conductivity, the oxygen permeation rate of the former series first decreases with decreasing Co content and then increases. $\mathrm{LaFe}_{0.4} \mathrm{Ni}_{0.4} \mathrm{Co}_{0.2} \mathrm{O}_{3}$ shows the highest oxygen permeation rate of $0.016 \mathrm{ml} \mathrm{cm}^{-2} \mathrm{~min}^{-1}$ at $950{ }^{\circ} \mathrm{C}$. In the latter series, the oxygen permeation decreases with increasing $\mathrm{Fe}$ content. Here, $\mathrm{LaNi}_{0.5} \mathrm{Co}_{0.5} \mathrm{O}_{3}$ shows the highest oxygen permeation rate $\left(0.017 \mathrm{ml} \mathrm{cm}^{-2} \mathrm{~min}^{-1}\right.$ at $\left.950{ }^{\circ} \mathrm{C}\right)$. These values are in agreement with previously published data on $\mathrm{LaNi}_{0.5} \mathrm{Fe}_{0.5} \mathrm{O}_{3}$ [32]. However, the oxygen permeation is significantly smaller than the state-of-the-art $(\mathrm{La}, \mathrm{Sr})(\mathrm{Co}, \mathrm{Fe}) \mathrm{O}_{3}$ cathode materials. For example, $\mathrm{La}_{0.38} \mathrm{Sr}_{0.6} \mathrm{Fe}_{0.2} \mathrm{Co}_{0.8} \mathrm{O}_{3}$ and $\mathrm{La}_{0.58} \mathrm{Sr}_{0.4} \mathrm{Fe}_{0.2} \mathrm{Co}_{0.8} \mathrm{O}_{3}$ show oxygen permeation rates of $0.5 \mathrm{ml} \mathrm{cm}$ $\min ^{-1}$ and $0.3 \mathrm{ml} \mathrm{cm}^{-2} \min ^{-1}$ at $950{ }^{\circ} \mathrm{C}$, respectively [35]. Considering most of the samples in this study have sufficient electrical conductivities, the low oxygen permeation rate should result in limited catalytic activity for oxygen reduction reaction or low oxygen-ion conductivity. 


\section{Thermal expansion}

The thermal expansion coefficients (TECs) between room temperature and $800{ }^{\circ} \mathrm{C}$ measured on the perovskite compositions are presented in Fig. 7. As in other perovskite systems [8, 33], the thermal expansion is mainly controlled by the cobalt content and increases with increasing Co content. In the Co-free system $\mathrm{LaNi}_{\mathrm{x}} \mathrm{Fe}_{1-\mathrm{x}} \mathrm{O}_{3}$, the TEC increases with increasing $\mathrm{Ni}$ content and values of $10.9 \times 10^{-6} \mathrm{~K}^{-1}$ and $11.9 \times 10^{-6} \mathrm{~K}^{-1}$ have been reported for $\mathrm{LaNi}_{0.5} \mathrm{Fe}_{0.5} \mathrm{O}_{3}$ [20,32]. In this study, however, a TEC of $13.2 \times 10^{-6} \mathrm{~K}^{-1}$ was measured and the opposite trend was observed: the TEC decreased with increasing $\mathrm{Ni}$ content in the series $\mathrm{LaNi}_{0.5-x} \mathrm{Fe}_{x} \mathrm{Co}_{0.5} \mathrm{O}_{3}$. The measured TEC value of $\mathrm{LaNi}_{0.5} \mathrm{Co}_{0.5} \mathrm{O}_{3}\left(16.9 \times 10^{-6} \mathrm{~K}^{-1}\right)$ is also higher than the value reported for $\mathrm{LaNi}_{0.6} \mathrm{Co}_{0.4} \mathrm{O}_{3}\left(15.0 \times 10^{-6} \mathrm{~K}^{-1}[20]\right)$ and may be due to the higher Co content. The TEC of $\mathrm{LaCoO}_{3}\left(22.1 \times 10^{-6} \mathrm{~K}^{-1}\right)$ is in very good agreement with previous studies [6,30].

\section{Mössbauer spectroscopy}

The oxidation state and the local environment of $\mathrm{Fe}$ in the different $\mathrm{LaNi}_{0.5-x} \mathrm{Fe}_{x} \mathrm{Co}_{0.5} \mathrm{O}_{3}$ and $\mathrm{La}\left(\mathrm{Ni}_{0.5} \mathrm{Fe}_{0.5}\right)_{1-x} \mathrm{Co}_{x} \mathrm{O}_{3}$ samples were studied by ${ }^{57} \mathrm{Fe}$ Mössbauer spectroscopy. The room temperature Mössbauer spectra of $\mathrm{LaNi}_{0.5-x} \mathrm{Fe}_{x} \mathrm{Co}_{0.5} \mathrm{O}_{3}$ materials have a doublet shape as illustrated in Fig. 8a. All spectra are consistent with the presence of paramagnetic iron, confirming the absence of any magnetic ordering at room temperature. Good quality fits of the data have been obtained using only one doublet, and the isomer shift and quadrupole splitting value are in good agreement with the existence of only one iron site, occupied by high-spin $\mathrm{Fe}^{3+}$. 
With increasing substitution and iron content, the change in spectral shape suggests changes in the local iron environment. The corresponding spectral parameters are given in Table 4 .

The values of both the isomer shift $(\delta)$ and the quadrupole splitting $(\Delta)$ decrease slightly with increasing $x$. The decrease in the iron content $x$ is also accompanied by a decrease in unit cell volume, see Table 2 , and thus with an increase in the electron density, $\rho_{\mathrm{e}}$, which typically leads to a decrease in $\delta$. Considering the double substitution ( $\mathrm{Ni}, \mathrm{Fe}) \rightarrow \mathrm{Co}$ (see below), it is, however, more likely that the decrease in isomer shift is related to a direct partial charge transfer from $\mathrm{Ni}$ to Fe. Only a small quadrupole shift (QS) is detectable at $10 \mathrm{~K}$ (see below), which is surprising as usually the quadrupole splitting of $\mathrm{Fe}(\mathrm{III})$ does not exhibit any strong temperature dependence. The relation between the quadrupole shift and the quadrupole splitting is given by $\mathrm{QS}=\Delta \cdot\left(3 \cos ^{2}(\theta)-1\right) / 2$. Thus, either the relative angle $\theta$ between the iron magnetic moment and the principal axis of the electric field gradient $V_{\mathrm{zz}}$ is close to the magic angle, $54.7^{\circ}$, or a change in the local symmetry occurs upon crossing the boundary between the magnetic and paramagnetic phase. Note that in $\mathrm{Mn}$ substituted perovskite $\mathrm{EuFeO}_{3}[36]$ the substitution of $\mathrm{Fe}$ by Mn does both weaken the magnetic exchange interaction and induces a Jahn-Teller distortion that leads to a large electric field gradient for the iron ions. A similar scenario cannot be excluded here but its exploring is beyond the scope of this work.

The Mössbauer spectra of $\mathrm{LaNi}_{0.5-\mathrm{x}} \mathrm{Fe}_{x} \mathrm{Co}_{0.5} \mathrm{O}_{3}$ recorded at $10 \mathrm{~K}$ are shown in Figure $8 \mathrm{~b}$ and their corresponding hyperfine Mössbauer parameters are presented in Table 5. All spectra exhibit well-resolved sextets and a single broadened magnetic sextet was sufficient to fit the recorded spectra originating from a single valence state of iron $\left(\mathrm{Fe}^{3+}\right)$ occupying a single crystallographic site. All samples exhibit sextets with a $\delta$ between 0.40 and $0.46 \mathrm{~mm} / \mathrm{s}$, which is typical for high- 
spin $\mathrm{Fe}^{3+}$. The isomer shift for all samples at $10 \mathrm{~K}$ is $\sim 0.11 \mathrm{~mm} / \mathrm{s}$ larger than at room temperature. This difference originates in the second-order Doppler shift [37].

The value of quadrupole splitting is zero within the error-bar for all samples, which confirms the absence of a contribution to the electric field gradient at $10 \mathrm{~K}$. This agrees well with the rhombohedral structure of the studied materials. The average of the magnetic field corresponds to sixfold-coordinated $\mathrm{Fe}^{3+}$ ions [38] and decreases with increasing $x$. The magnetic hyperfine field $\mathrm{B}_{\mathrm{hf}}=\mu_{0} \mathrm{H}_{\mathrm{hf}}$ for the parent component is $50.2 \mathrm{~T}$ and is in good agreement with iron-based perovskite materials [39]. High-spin $\mathrm{Fe}^{3+}$ with a coordination number of 5 or 6 usually has a saturation field of more than $50 \mathrm{~T}$. The decrease of magnetic hyperfine field with increasing $\mathrm{Ni}$ concentration can be attributed to the substitution of the magnetic element $\left(\mathrm{Fe}^{3+}\right.$, high spin) with a magnetic element with smaller moment.

The Mössbauer spectra of $\mathrm{La}\left(\mathrm{Ni}_{0.5} \mathrm{Fe}_{0.5}\right)_{1-x} \mathrm{Co}_{x} \mathrm{O}_{3}$ recorded at room temperature are presented in Fig 9a. Their corresponding Mössbauer parameters are shown in Table 6. The Mössbauer spectrum of $\mathrm{LaNi}_{0.5} \mathrm{Fe}_{0.5} \mathrm{O}_{3}$ was analyzed using two doublets attributed to two $\mathrm{Fe}^{3+}$ components. Indeed, two pronouncedly separated surroundings of Fe ions can be distinguished, which is in good agreement with the XRD results indicating 60\% rhombohedral and $40 \%$ orthorhombic phase. The isomer shifts of two iron sites are very similar and typical for high-spin $\mathrm{Fe}^{3+}$ in the octahedral or pyramidal coordination [40]. All compounds in the studied series $\mathrm{La}\left(\mathrm{Ni}_{0.5} \mathrm{Fe}_{0.5}\right)_{1 \text { - }}$ ${ }_{x} \mathrm{Co}_{x} \mathrm{O}_{3}(0<x<0.8)$ exhibit approximately the same isomer shift equal to $\sim 0.32 \mathrm{~mm} / \mathrm{s}$ confirming that the combined substitution of Ni and Fe by Co does not significantly modify the $s$-electron density. The decrease in $x$ is accompanied by a volume change similar to that observed in the $\mathrm{Fe} \rightarrow \mathrm{Ni}$ substitution series without leading here to a modification of the isomer shift. This difference indicates that the origin of the isomer shift change is due to the electron transfer in the 
$\mathrm{Fe} \rightarrow \mathrm{Ni}$ substitution series. Note that the $(\mathrm{Fe}, \mathrm{Ni}) \rightarrow$ Co substitution is an isoelectronic one. Two components are required in analyzing the Mössbauer spectra of this series both at room temperature and low temperature, likely due to the biphasic nature or a pronounced variation in the local environment that originates from cobalt, nickel and iron randomly distributed over the second nearest neighbor sites of an iron ion [41].

The Mössbauer spectra of $\mathrm{LaNi}_{0.3} \mathrm{Fe}_{0.3} \mathrm{Co}_{0.4} \mathrm{O}_{3}$ recorded at $10 \mathrm{~K}$ cannot be fitted using only one component and for the parent material $\mathrm{LaNi}_{0.5} \mathrm{Fe}_{0.5} \mathrm{O}_{3}$ the $\mathrm{XRD}$ result is in good agreement with the existence of two components. With increasing concentration of Co ions, $x$, the relative intensity of the two components changes in the Mössbauer spectra. The relative area of the first component peak significantly decreases from 62 to $15 \%$. Variations in the quadrupole splitting are also likely related to a local structural distortion due to the Jahn-Teller effect upon substitution.

Fig. $9 \mathrm{~b}$ shows the spectra collected at $10 \mathrm{~K}$ (below the Néel temperature), which exhibit a magnetic sextet shape indicating that the materials are magnetically ordered. Table 7 summarizes the Mössbauer parameters estimated from the Mössbauer spectra. For increasing Co content $x$ the isomer shift is constant within the limits of experimental error and the quadrupole splitting exhibits the same behavior as observed at room temperature. The hyperfine field $B_{h f}$ values of two $\mathrm{Fe}^{3+}$ decrease with increasing cobalt ion concentration $(x)$ likely due to increasing site disorder. Spectra at $10 \mathrm{~K}$ could not be measured in a reasonable time for samples with $x>0.4$ due to the low iron content.

\section{Conclusions}


The compounds investigated in the quasi-ternary system $\mathrm{LaFeO}_{3}-\mathrm{LaCoO}_{3}-\mathrm{LaNiO}_{3}$ revealed interesting materials for applications in electrochemical or membrane devices due to their high electronic conductivities and moderate thermal expansion coefficients. Compared with Srcontaining perovskites, the smaller oxygen permeation rate (or oxygen ion conductivity) can be compensated by adding oxygen ion conductors and using composite materials, as has already been shown for $\mathrm{Zr}_{1-\mathrm{x}} \mathrm{Y}_{\mathrm{x}} \mathrm{O}_{2-\mathrm{x} / 2} / \mathrm{La}_{1-\mathrm{y}} \mathrm{Sr}_{\mathrm{y}} \mathrm{MnO}_{3}$ cathodes [42]. The Mössbauer investigations showed iron as $\mathrm{Fe}^{3+}$ and only little oxygen non-stoichiometry might be expected in these materials. Overall, the investigated materials will pave the way to develop Sr-free and hence degradationreduced electrodes for SOFCs and membranes. Considering matching thermal expansion coefficients with other SOFC components and satisfying high electrical conductivities, the materials with a cobalt content of $\leq 0.5$ mol Co per formula unit are most interesting for SOFC cathode materials.

\section{Acknowledgements}

The research leading to these results received funding from the European Union's Seventh Framework Program (FP7/2007-2013) for the Fuel Cells and Hydrogen Joint Technology Initiative under grant agreement no. 256730. The authors thank colleagues at ZEA-3, Forschungszentrum Jülich, for ICP-OES measurements, M. Ziegner (IEK-2, Forschungszentrum Jülich) for XRD measurements, and Prof. F. Grandjean for helpful discussions. A. Mahmoud acknowledges Forschungszentrum Jülich for an international postdoctoral grant. Work at Oak Ridge National Laboratory was supported by the U.S. Department of Energy, Office of Science, Basic Energy Sciences, Materials Sciences and Engineering Division. 


\section{References}

[1] B. C. H. Steele, A. Heinzel, Nature 414 (2001) 345-352

[2]M. Mogensen, S. Skaarup, Solid State Ionics 86-88 (1996) 1151-1160

[3]H. Yokokawa, H. Tu, B. Iwanschitz, A. Mai, J. Power Sources 182 (2008) 400-412

[4] A. Mai, V. A. C. Haanappel, S. Uhlenbruck, F. Tietz, D. Stöver, Solid State Ionics 176 (2005) 1341-1350

[5] S. P. Simner, J. F. Bonnett, N. L. Canfield, K. D. Meinhardt, V. L. Sprenkle, J. W. Stevenson, Electrochem. Solid-State Lett. 5 (2002) A173-A175

[6] A. Petric, P. Huang, F. Tietz, Solid State Ionics 135 (2000) 719-725

[7] F. Tietz, I. Arul Raj, M. Zahid, D. Stöver, Solid State Ionics 177 (2006) 1753-1756

[8] F. Tietz, I. Arul Raj, M. Zahid, A. Mai, D. Stöver, Progr. Solid State Chem. 35 (2007) 539543

[9] M. Zahid, I. Arul Raj, F. Tietz, D. Stöver, Solid State Sci. 9 (2007) 706-712

[10] D. H. Peck, M. Miller, H. Nickel, D. Das, K. Hilpert, Proc. 4th Int. Symp. Solid Oxide Fuel Cells (SOFC-IV), eds. M. Dokiya, O. Yamamoto, H. Tagawa, S. C. Singhal, The Electrochemical Society, Pennington, NJ, 1995, pp. 858-868.

[11] S. P. S. Badwal, R. Deller, K. Föger, Y. Ramprakash, J. P. Zhang, Solid State Ionics, 99 (1997) 297-310

[12] S. P. Jiang, J. P. Zhang, L. Apateanu, K. Föger, J. Electrochem. Soc. 147 (2000) 4013-4022

[13] N. H. Menzler, P. Batfalsky, S. M. Groß, V. Shemet, F. Tietz, ECS Transact. 35 (1) (2011) $195-206$ 
[14] E. Konysheva, H. Penkalla, E. Wessel, J. Mertens, U. Seeling, L. Singheiser, K. Hilpert, J. Electrochem. Soc. 153 (2006) A765 -A773

[15] S. P. Jiang, S. Zhang, Y. D. Zhen, J. Electrochem. Soc. 153 (2006) A127-A134

[16] L. Niewolak, J. W. Quadakkers, F. Tietz, in: "High-temperature Solid Oxide Fuel Cells for the 21st Century", eds.: K. Kendall, M. Kendall, ISBN 978-0-12-410453-2, Elsevier, 2016, chapter 7 , pp. 195-254

[17] J. Sunarso, S. Baumann, J. M. Serra, W. A. Meulenberg, S. Liu, Y.S. Lin, J. C. Diniz da Costa, J. Membr. Sci. 320 (2008) 13-41

[18] M. Arnold, H. Wang, A. Feldhoff, J. Membr. Sci. 293 (2007) 44-52

[19]S. Engels, T. Markus, M. Modigell, L. Singheiser, J. Membr. Sci. 370 (2011) 58-69

[20] R. Chiba, F. Yoshimura, Y. Sakurai, Solid State Ionics 124 (1999) 281-288

[21] H. Orui, K.Watanabe, R. Chiba, M. Arakawa, J. Electrochem. Soc. 151 (9) (2004) A1412A1417

[22] H. Orui, K. Nozawa, R. Chiba, T. Komatsu, K. Watanabe, S. Sugita, H. Arai, M. Arakawa, ECS Transact. 7 (2007) 255-261

[23] T. Komatsu, H. Arai, R. Chiba, K. Nozawa, M. Arakawa, K. Sato, Electrochem. Solid-State Lett. 9 (2006) A9-A12

[24] M. P. Pechini, US Patent No. 3,330,697, July 1967

[25] S. Baumann, F. Schulze-Küppers, S. Roitsch, M. Betz, M. Zwick, E. M. Pfaff, W. A.

Meulenberg, J. Mayer, D. Stöver, J. Membrane Sci. 359 (2010) 102-109

[26] H. Taguchi, T. Komatsu, R. Chiba, K. Nozawa, H. Orui, H. Arai, Solid State Ionics 182 (2011) 127-132

[27] R. D. Shannon, Acta Crystallogr. A32 (1976) 751-767 
[28]J. E. Millburn, M. J. Rosseinsky, Chem. Mater. 9 (1997) 511-522

[29] M. A. Señarís-Rodríguez, J. B. Goodenough, J. Solid State Chem. 118 (1995) 323

[30] F. Tietz, Proc. 9th CIMTEC-World Ceramic Congress and Forum on New Materials, ed. P. Vincenzini, Techna Publishers S.r.1., Faenza, Italy, Vol. 24: Innovative Materials in Advanced Energy Technologies (1999), pp. 61-70

[31] K. S. Roh, K. H. Ryu, C. H. Yo, J. Solid State Chem. 142 (1999) 288-293

[32] V. V. Kharton, A. P. Viskup, E. N. Naumovich, V. N. Tikhonovich, Mater. Res. Bull. 34 (1999) 1311-1317

[33] X. Montero, W. Fischer, F. Tietz, M. Cassir, D. Stöver, I. Villareal, Solid State Ionics 180 (2009) 731-737

[34] A. Mineshige, J. Izutsu, M. Nakamura, K. Nigaki, J. Abe, M. Kobune, S. Fujii, T. Yazawa, Solid State Ionics 176 (2005) 1145-1149

[35] F. Schulze-Küppers, S. Baumann, F. Tietz, H. J. M. Bouwmeester, W. A.Meulenberg, J. Eur. Ceram. Soc. 34 (2014) 3741-3748

[36] L.-P. Li, X.-Y. Song, W.-H. Su, Q. Wei, Z.-J. Kang, Hyperfine Interactions 116 (1998) 167112

[37] Y.-L. Chen, D. Yang, Mössbauer effect in lattice dynamics: experimental techniques and applications. Wiley-VCH, Weinheim, 2007

[38] M. Romero, R.W. Gómez, V. Marquina, J.L. Pérez-Mazariego, R. Escamilla, Physica B: Condensed Matter 443 (2014) 90-94

[39] H. El Shinawi, J. F. Marco, F. J. Berry, C. Greaves, J. Solid State Chem. 182 (2009) 22612268 
[40] L. Samain, P. Amshoff, J. J. Biendicho, F. Tietz, A. Mahmoud, R. P. Hermann, S. Ya.

Istomin, J. Grins, G. Svensson, J. Solid State Chem. 227 (2015) 45-54

[41] K. Świerczek, J. Marzec, D. Pałubiak, W. Zając, J. Molenda, Solid State Ionics 177 (2006)

$1811-1817$

[42] V. A. C. Haanappel, J. Mertens, D. Rutenbeck, C. Tropartz, W. Herzhof, D. Sebold, F.

Tietz, J. Power Sources 141 (2005) 216-226 


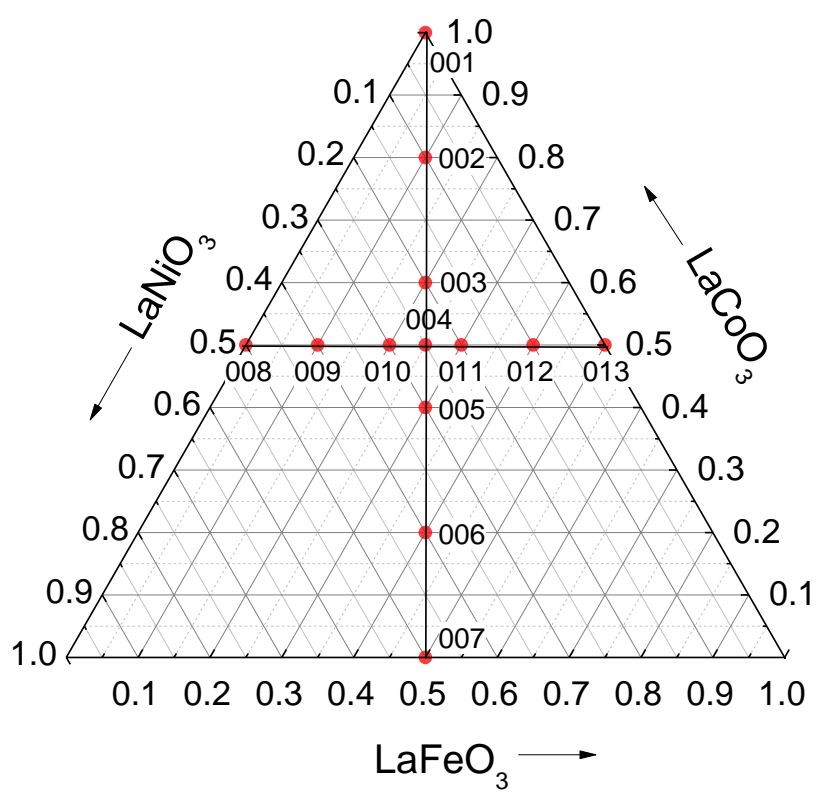

Figure 1 

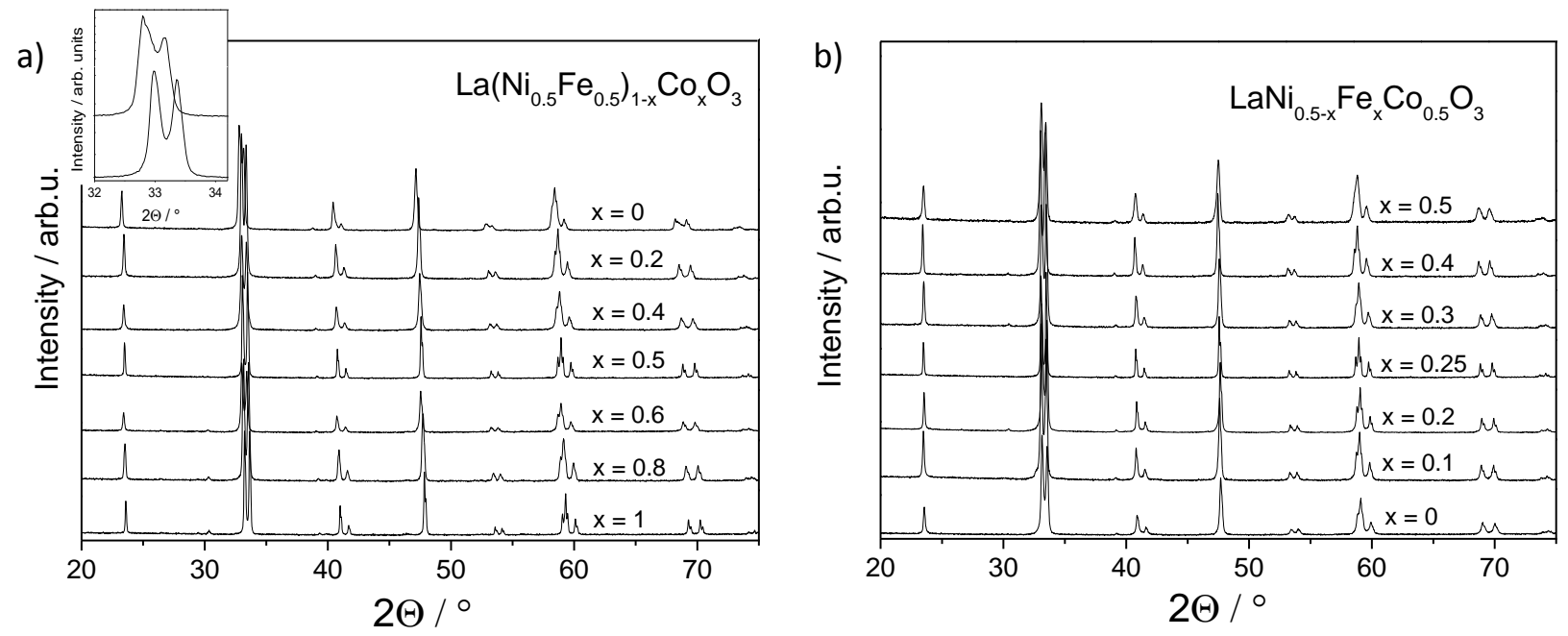

Figure 2 


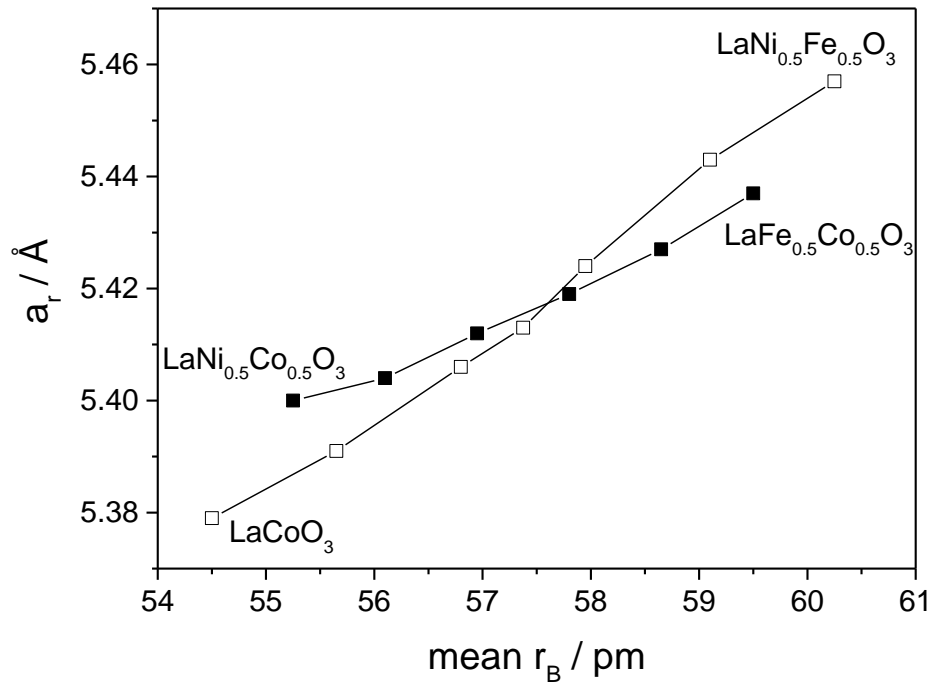

Figure 3 

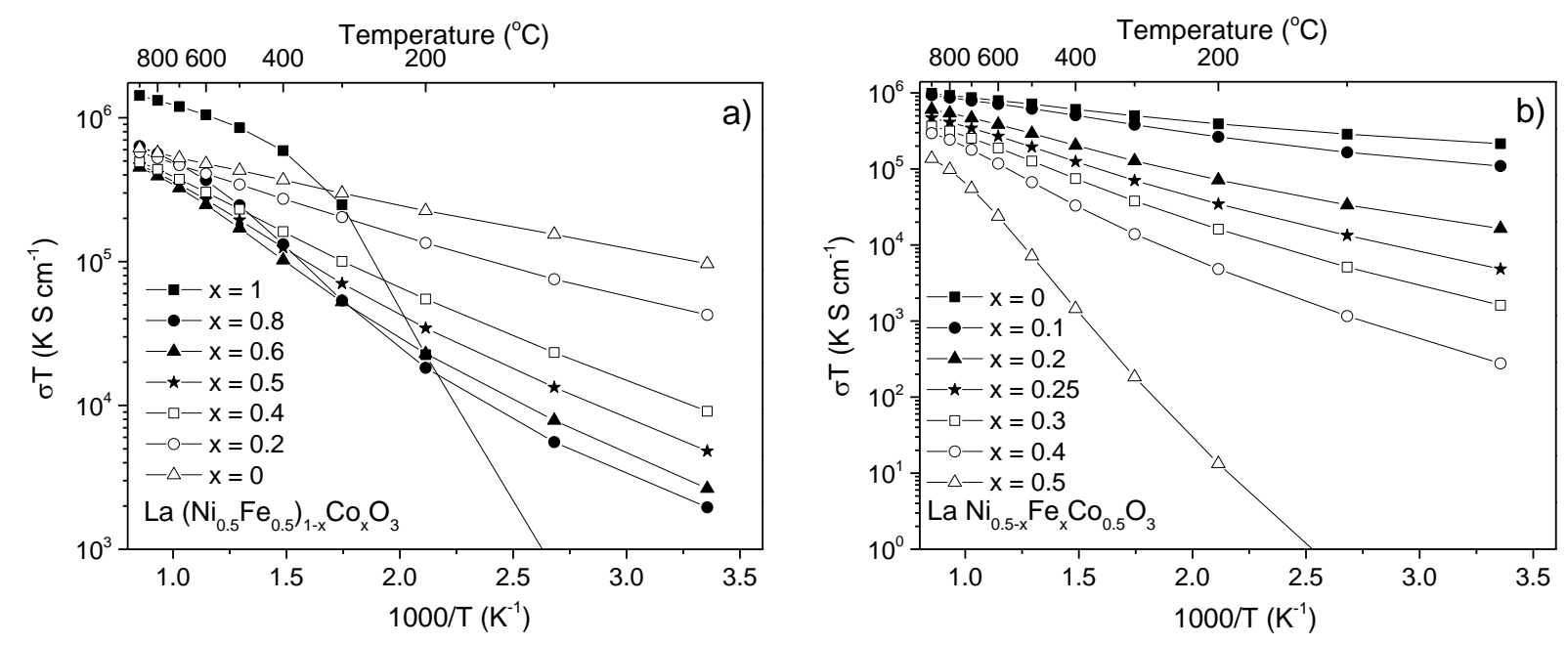

Figure 4 


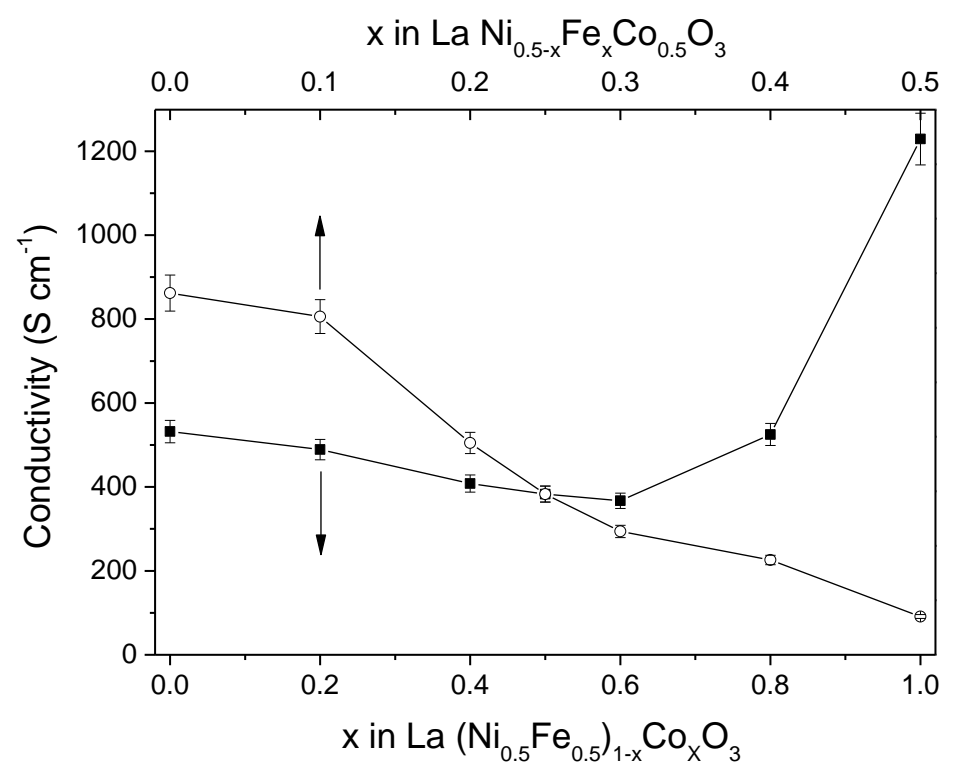

Figure 5 

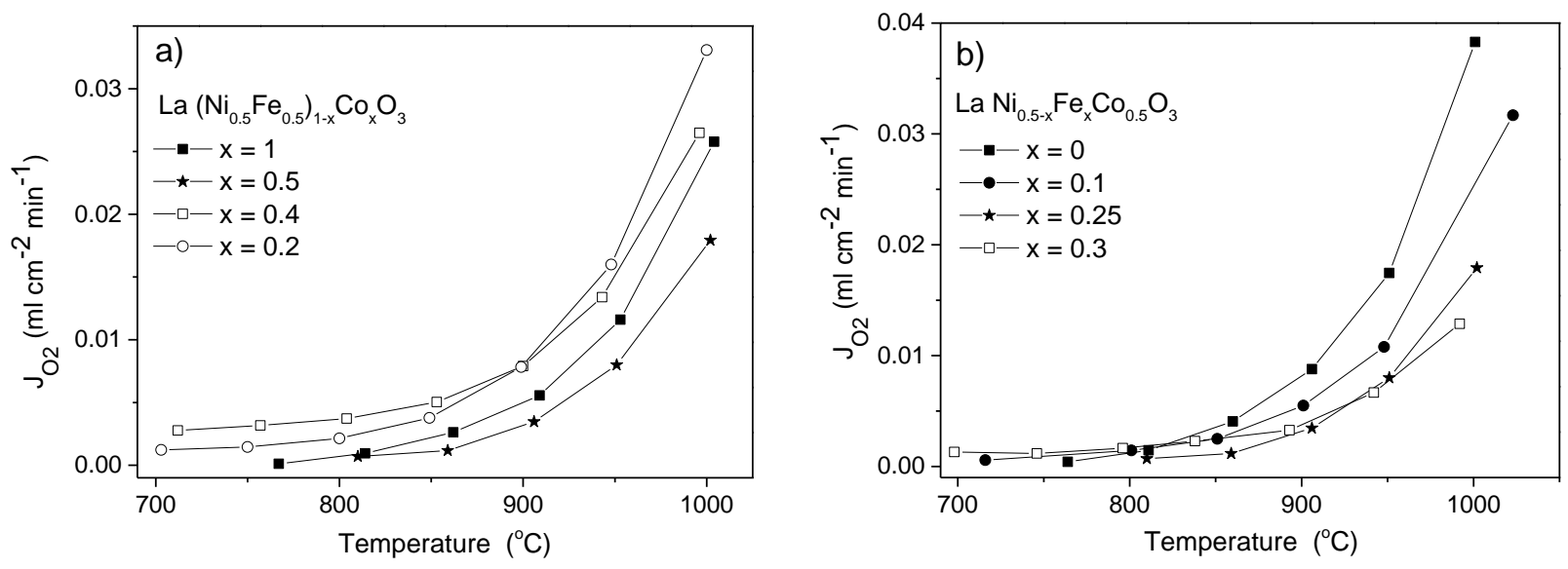

Figure 6 


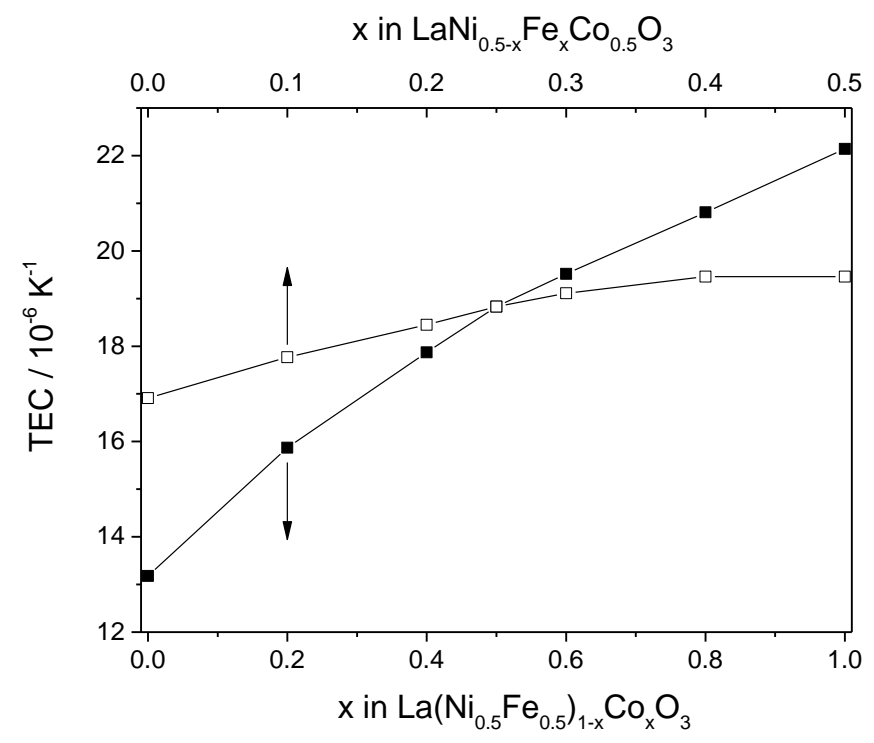

Figure 7 

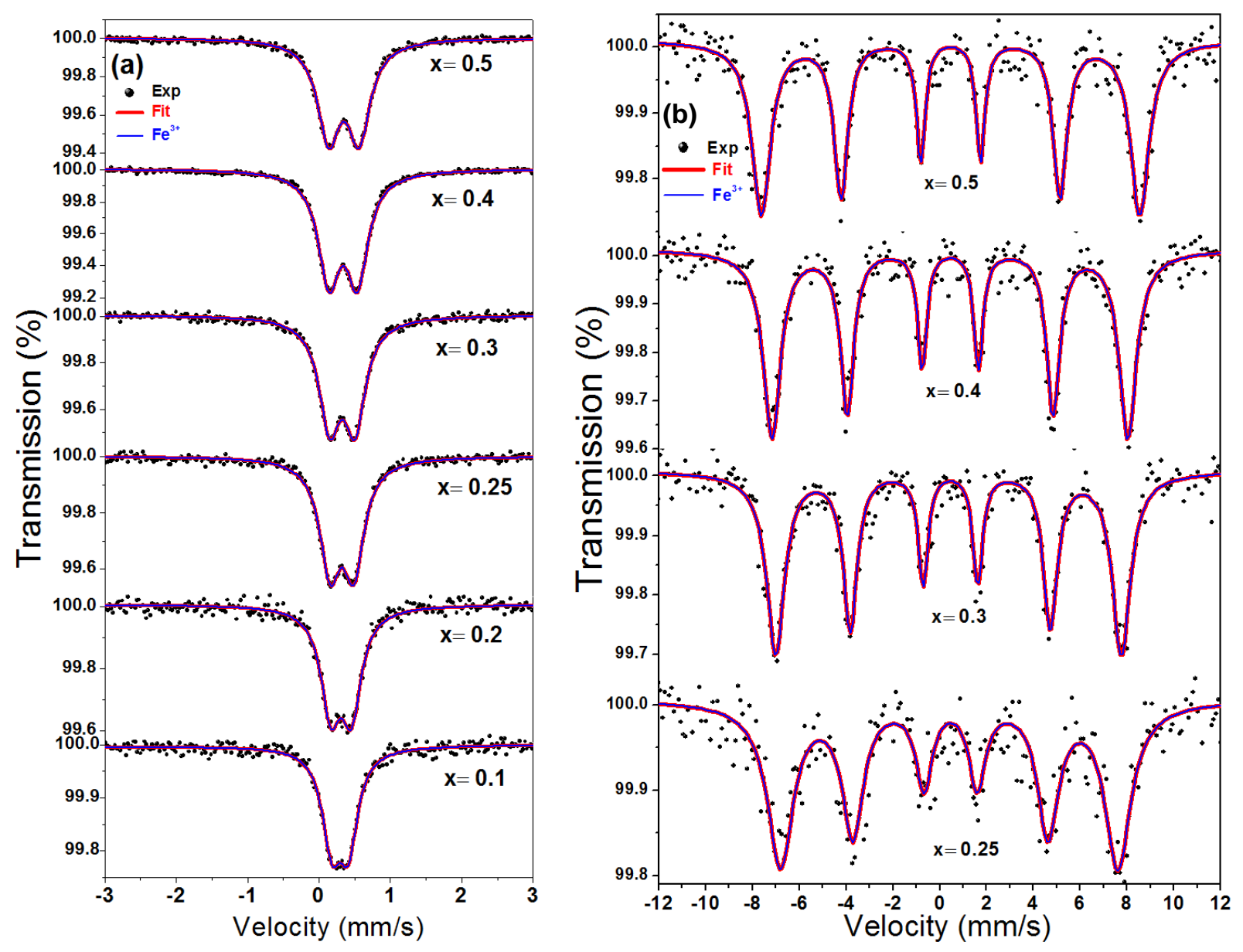

Figure 8 

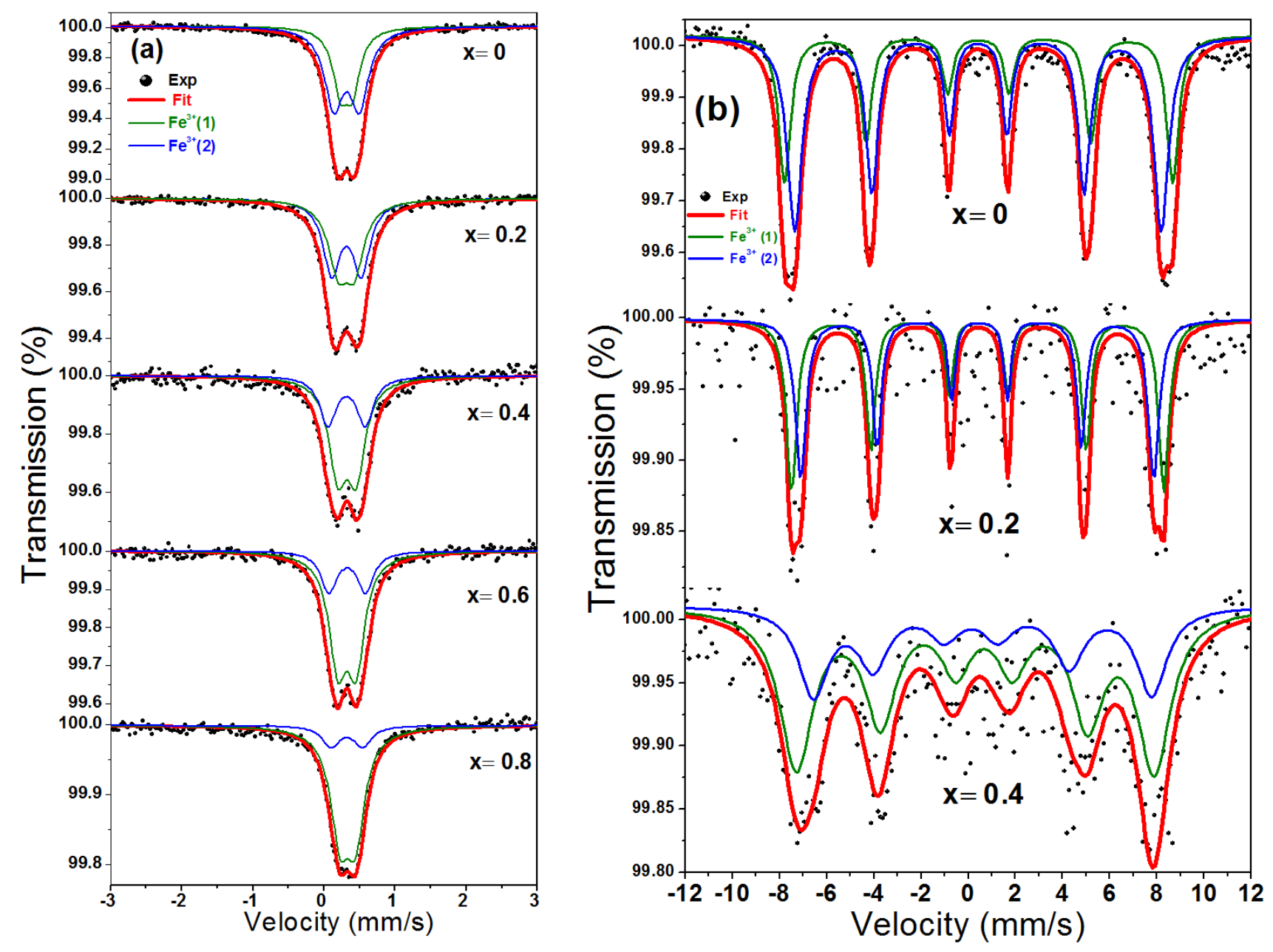

Figure 9 
Table of Contents

Figure

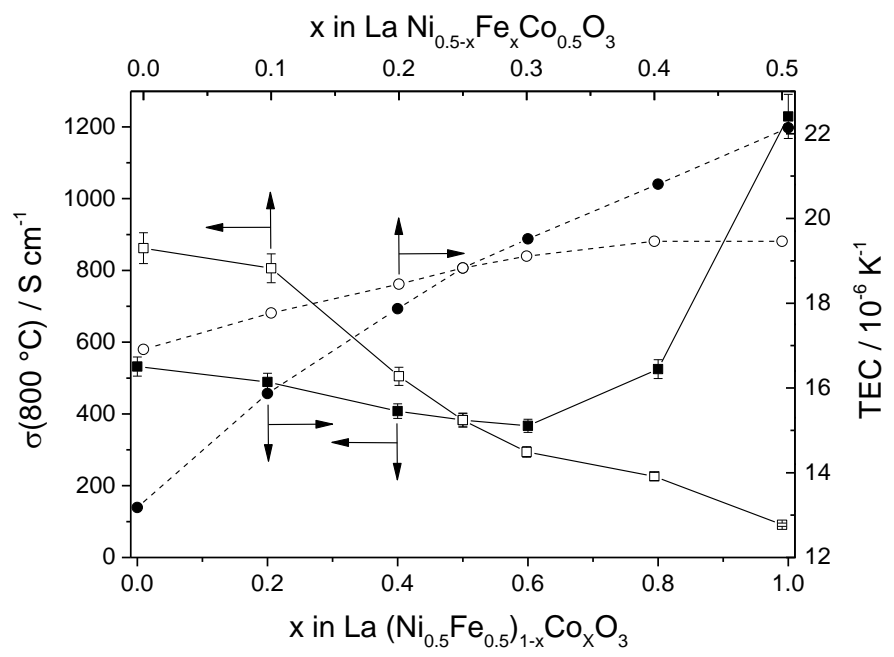

